Ethiopian Journal of Environmental Studies \& Management 7(3): 244 - 252, 2014.

ISSN: 1998-0507

doi: http://dx.doi.org/10.4314/ejesm.v7i3.3

Submitted: December 2. 2013

Accepted: March 25, 2014

\title{
MONITORING SPATIAL-TEMPORAL VARIABILITY OF AEROSOL OVER KENYA
}

\author{
*NGAINA, J.N., MUTAI, B.K., ININDA, J.M. AND MUTHAMA, J.N. \\ ${ }^{1}$ Department of Meteorology, University of Nairnbi, P.O Box 30197 - 00100 GPO, Nairobi
}

\begin{abstract}
This study sought to investigate the spatial and temporal variations of aerosols over Kenya based on Moderate Resolution Imaging Spectroradiometer (MODIS) satellite sensor Aerosol Optical Depth (AOD) data for the period between 2001 and 2012. A Hybrid Single Particle Lagrangian Integrated Trajectory (HYSPLIT) model was used for trajectory analysis in order to reconstruct the origins of air masses and understand the Spatial and temporal variability of aerosol concentrations. Validation of MODIS AOD using Aerosol Robotic Network (AERONET) indicated that MODIS overestimated the aerosol loading over the study region. Space time variability of MODIS AOD measurements over Kenya showed a decreasing trend in aerosol loading with a long term mean of between 0.02 and 0.56. Mean monthly AOD values showed two peaks during the months of July and December while seasonal variations indicated high aerosol loading during the DecemberJanuary -February (DJF) and June -July -August (JJA) season. Back trajectory analyses showed that aerosols mainly dust and sea salt reaching Kenya were transported from either Arabian or Indian sub continent or western parts of the Indian Ocean respectively. Therefore, long term and more comprehensive satellite $A O D$ retrievals are necessary in order to achieve a better understanding of spatial and temporal variations in aerosols over Kenya
\end{abstract}

Key Words: Aerosol Optical Depth, MODIS, Kenya

\section{Introduction}

Atmospheric aerosols play a significant role in energy balance of the earth-atmosphere system. Changes in the atmospheric aerosol load, greenhouse gases, solar radiation, and land surface properties alter the energy balance of earth's atmosphere (Papadimas et al., 2008). According to IPCC (2007) report, aerosols have been recognized as a major factor in determining the global climate change in the last two decades as they play a crucial role in the solar and thermal radiative transfer in the atmosphere.

It is noted that aerosols not only affect the solar radiation budget at the surface of the earth and in the atmosphere but also on the hydrological cycle and precipitation rate (Lohmann and Feichter, 2005; Kosmopoulos et al., 2008). Moreover, dust particles modify the transmission of both short-wave and long-wave radiation through the atmosphere through atmospheric scattering and absorption processes (Otto et al., 2007) and consequently produce heating in the atmospheric column due to dust absorption (Haywood et al., 2001). Significant efferts on non _rlimatic related nroresses sulch as human health and ecosystem services have been noted (Smart et al., 2011). Increasing aerosol loading has mainly been attributed to biomass burning and boreal forest fire aerosol events and thus exacerbated the existing problems associated with air quality and public health (Torres et al., 2002).

Several studies have used satellite measurements to monitor space time characteristics of aerosols, at both regional and global scales (Kaufman et al., 2005; Matheson et al., 2005). Satellite remote sensing technique allows both spatial and temporal pattern and properties of aerosols to be assessed (Kosmopoulos et al., 2008). The spatio-temporal processes involved can then be indirectly described and mapped through modelling techniques, e.g., by using the USA's National Oceanic and Atmospheric Administration (NOAA) HYSPLIT model (Draxler and Rolph, 2003). In several urban areas of Europe, the United States, Australia, and some regions of Asia, the mass concentration of ambient aerosol particles is routinely measured by ground stations. However, individual ground-based

*Corresponding Author: Ngaina, J.N.

Email: jngaina@gmail.com 
observations represent point measurements and do not have coverage required to map regional or global distributions of aerosols. One major advancement in this respect has been the introduction of the AERONET Aerosol Robotic Network (Holben et al., 1998), which means that satellite remote sensing of aerosols no longer needs to be largely independent but can be tied in to this coordinated and harmonized ground data.

Studies by Chu et al. (2003) and Wang and Christopher (2003) showed great potential for mapping the distribution and properties of aerosols, and for deriving indirect estimates of particulate matter using MODIS satellite data. Gupta et al. (2008) noted that sparse distribution of ground based measurements makes it inevitable for the use of satellite data as a proxy measure for the monitoring of particulate matter air quality. Concern about atmospheric particulate pollution is growing worldwide with abundance and compositions of aerosols differing due to physical processes and their origin (Mkoma and Mjemah, 2011) which influences their spatial and temporal variability. Moreover, Mkoma and Mjemah (2011) noted higher PM10 mass concentrations $\left(45 \mu \mathrm{g} / \mathrm{m}^{3}\right)$ during the 2005 dry season and the lowest $(13 \mu \mathrm{g} / \mathrm{m} 3)$ during the 2006 wet season which were attributed to temperature inversions and absence of rain wash down. Other studies on transport and dispersion of aerosols based on satellite data exist (De Graaf et al., 2010; Mbithi, 2010).

Aerosol concentrations are continually increasing in virtually all urbanized and industrialized regions because of growing populations, rapid urbanization with consequent land use changes, increasing motorized traffic, and increasing industrialization within, and adjacent to, urban areas. There are, to date, relatively few studies on aerosols over Kenya. Nevertheless, ground-based measurements require expensive software or permanent automatic monitoring stations. Therefore, the study sought to investigate the spatio-temporal variability of aerosols based on MODIS AOD data over Kenya in order to understand the effects that aerosols have on the earth's climate system and human health they must be routinely monitored, both on a global scale and on regional or local scales, in particularly by analyzing their spatial and temporal patterns. This will provide a better understanding of spatial and temporal variations in aerosols which greatly impacts air quality and thus act as basis for development of air quality related policy in Kenya.

\section{Area of Study}

Kenya, lies between latitudes $5^{\circ}$ North and $5^{\circ}$ south and between longitudes $34^{\circ}$ and $42^{\circ}$ east. It has a land area of about $569,137 \mathrm{~km}^{2}$ with great diversity of landforms ranging from glaciated mountain peaks with permanent snow cover, through a flight of plateaus to the coastal plain. The country is split by the Great Rift Valley into the Western part which slopes down into Lake Victoria from the Mau ranges and Mount Elgon $(4,300 \mathrm{~m})$ and the Eastern part which is dominated by Mt. Kenya and the Aberdare ranges that rise to altitudes of $5,200 \mathrm{~m}$ and $4,000 \mathrm{~m}$ respectively. It has got a distinct bimodal rainfall pattern which is influenced by the Inter Tropical Convergence Zone (ITCZ), global oceans, the tropical high pressure systems (Mascarene, St. Helena, Azores and Arabian), tropical monsoons and tropical cyclones (Ngaina and Mutai, 2013).

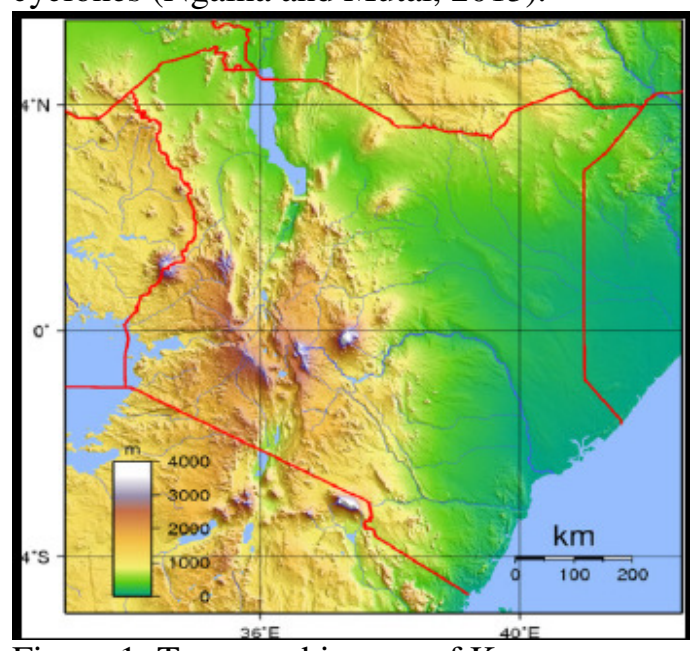

Figure 1: Topographic map of Kenya

Seasonal cycles of absorbing aerosols have distinct modes of residue distribution associated with dry periods and wet periods (De Graaf et al., 2010). During dry periods the residue varies freely, due to aerosol emissions from deserts and biomass burning events while during wet periods the residue depends linearly on the amount of precipitation, due to scavenging of aerosols and the prevention of aerosol emissions from the wet surface attributed to the sources and sinks of 
atmospheric aerosols being controlled directly by the local climate such as monsoonal precipitation Possible sources of aerosols in Kenya are Middle East, Sahara and Arabian deserts in the Northern hemisphere during the month of February while the Congo rain forest, Kalahari and Namibian deserts, Southern Atlantic Ocean, South west Indian Ocean, Madagascar Island and South African regions during the month of July (Mbithi, 2010). The transport of aerosols and their dispersion patterns greatly depend on the season of the year together with the prevailing atmospheric conditions.

\section{Materials and Methods}

Satellite aerosol properties from MODIS sensors were used in this study (http://daac.gsfc.nasa.gov/MODIS/Terra/atmosph ere/MOD08_M3.shtml) to understand and analyze the variability of aerosols over Kenya. Ground based AERONET AOD data was used to validate MODIS AOD which was obtained using Level-3 MODIS gridded atmosphere monthly global product 'MOD08_M3' at spatial resolution of $1^{0} \times 1^{0}$ (Ichoku et al., 2004).

The AERONET CIMEL sky ground-based data are available at three levels; Level 1.0 (unscreened), Level 1.5 (cloud screened) and Level 2.0 (quality assured) (Holben et al., 1998), which can be downloaded from the AERONET website (http://aeronet.gsfc.nasa.gov/). The CIMEL sun/sky radiometer takes measurements of direct sun and diffuses sky radiances within the $340-1020 \mathrm{~nm}$ and $440-1020 \mathrm{~nm}$ spectral ranges, respectively (Holben et al., 1998). The sun/sky radiometer retrieval accuracy is comprehensively explained and discussed by Dubovik et al. (2000).Version 2 cloud screened daily mean AOD $(500 \mathrm{~nm})$ direct sun data over Nairobi $\left(1^{0} \mathrm{~S}, 36^{0} \mathrm{E}\right)$ and ICIPE-Mbita $\left(0^{0} \mathrm{~S}, 34^{0} \mathrm{E}\right)$ in Kenya from 2007 to 2012 were used in the study.

The daily mean AODs $(500 \mathrm{~nm})$ from AERONET were first interpolated to a common $550 \mathrm{~nm}$ using the power law shown in equation 1 .
$\mathrm{AOD}_{\mathrm{ES0nm}}=\mathrm{AOD}_{\mathrm{EONmm}}\left(\frac{550}{500}\right)^{-n}$

Where $\alpha$ is the (440 $-870 \mathrm{~nm})$ Angstrom exponent (Prasad et al., 2007).

Interpolated ground based AERONET AOD data were then used to validate MODIS AOD over Eastern Africa. This was based on Percentage difference in the MODIS retrieved and AERONET AOD data computed using the equation 2. Comparison was also done based on the coefficient of determination $\left(\mathrm{R}^{2}\right)$ values over the stations.

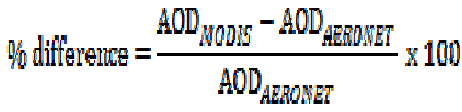

A positive value of the percentage difference implies an overestimation by MODIS.

Temporal variability was assessed using Mann Kendall Rank statistic while spatial analysis was based on Kriging method using Surfer software. In Mann Kendall trend tests, positive values are indicative of an increase in the constituent with time, whereas negative values indicate a decrease in the constituent with time with strength of the trend proportional to the magnitude of the MannKendall Rank Statistic (Helsel and Hirsch, 1992). A HYSPLIT model was used for backward trajectory analysis to compute simple air parcel and can be run interactively on the website (http://ready.arl.noaa.gov/HYSPLIT.php). A three day back trajectory analysis based on the NOAA HYSPLIT model (Draxler and Rolph, 2003) was used to understand the origins of the air masses arriving in region. The meteorological input for the trajectory model was the GDAS (Global Data Assimilation) dataset (reprocessed from National Centres for Environmental Prediction (NCEP) by Air Resources Laboratory).

\section{Results and Discussion \\ Validation of MODIS AOD at $550 \mathrm{~nm}$}

MODIS AOD product over Eastern Africa was validated based on AERONET AOD data from ICIPE -Mbita and Nairobi stations (Figure 2). 


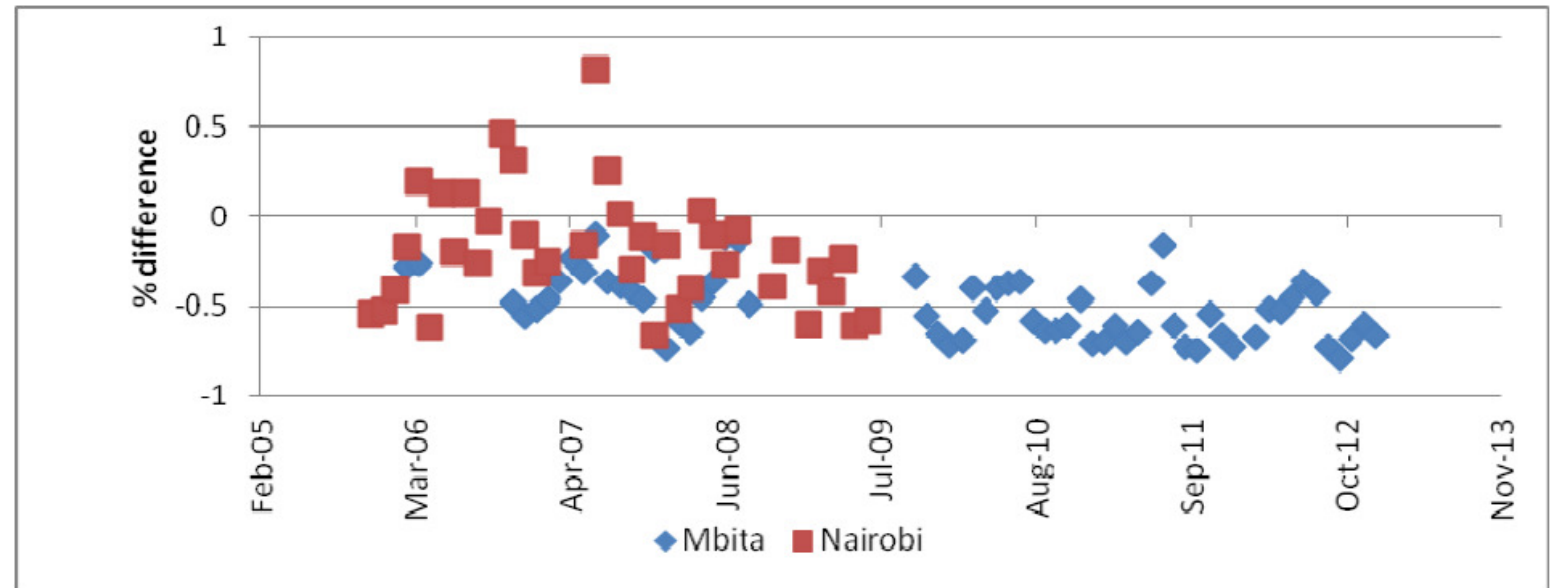

Figure 2: Percentage difference for AERONET and MODIS AOD over Mbita and Nairobi

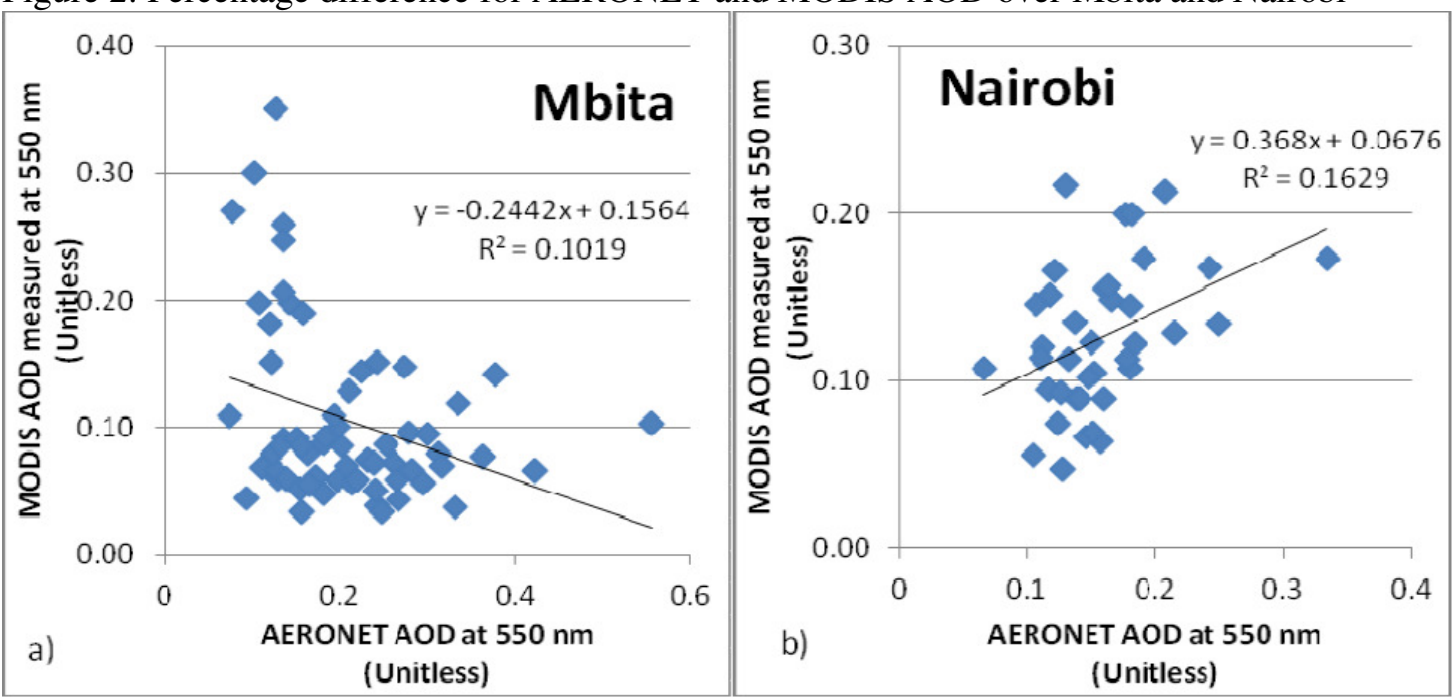

Figure 3: Validations of MODIS AOD with AERONET AOD at $550 \mathrm{~nm}$, over a) Mbita and b) Nairobi stations

Graphical plot of percentage difference between MODIS and AERONET AOD data over Mbita and Nairobi were found to have a mean of $-50 \%$ and $-19 \%$ respectively. These negative values indicated that MODIS sensor underestimated the amount of aerosol over the two stations considered.

The correlation coefficient for Mbita and Nairobi was found to be 0.81 and 0.55 . The $t$ test showed that these values were all significant as the $\mathrm{t}$ computed were all greater than the tabulated for the stations. However, regression analysis of between AERONET and MODIS AOD (Figure 3) noted that more data points were comparable over Nairobi than Mbita attributed to $\mathrm{R}^{2}$ values of 0.16 and 0.10 respectively. This implied that AOD estimates from MODIS over continental were better over terrestrial regions (Nairobi) than near water surfaces. This affirms results from Alam et al. (2011) which noted that MODIS AOD data provided better estimates over terrestrial and vegetated surfaces.

Overall, MODIS satellite were found to overestimate AOD values with observed differences attributed to issues such as consistency, revisit times, instrument calibration, sampling differences, and data availability (Liu et al., 2007; Kahn et al., 2007) for validation process

\section{Trend analysis}

Mann Kendall trend test (figure 4a) at 95\% significance level showed that most stations over western Kenya had significant negative trend in 
time series of MODIS AOD as p values were lower than alpha (0.05) while stations to the east of Kenya had no significant trend. The negative trends were attributed to the influence of transported pollution inlands as the region due to dominant South Easterlies and North Easterlies during a greater period of the year (Ngaina and Mutai., 2013; Okoola 1999).

\section{Annual and seasonal variations of AOD over} Kenya

Over Kenya, annual mean values of AOD (figure $4 \mathrm{~b}$ ) ranged from 0.02 to 0.56 . The high mean values close to the Indian Ocean were attributed to presence of high amounts of sea salt throughout the year while high AOD values over North and eastern parts of Kenya were attributed to dust.
Time series of mean monthly AOD values (figure 5) were noted to display two peaks during the months of July and December with the high aerosol loading linked to different process over different locations and times of the year. However, seasonal variations indicated high aerosol loading during DJF and JJA season (figure 6). The enhanced AOD loading were attributed to land clearing and agricultural fires that are widespread in the equatorial region during dry season (December January February) and dust storm events (Gautam et al., 2010) during monsoon seasons. Moreover, Rajeev et al. (2000) noted that in the western Indian Ocean and Arabian Sea, the high concentration of nonsea-salt aerosols were due to transport from the Indian subcontinent and Arabia.

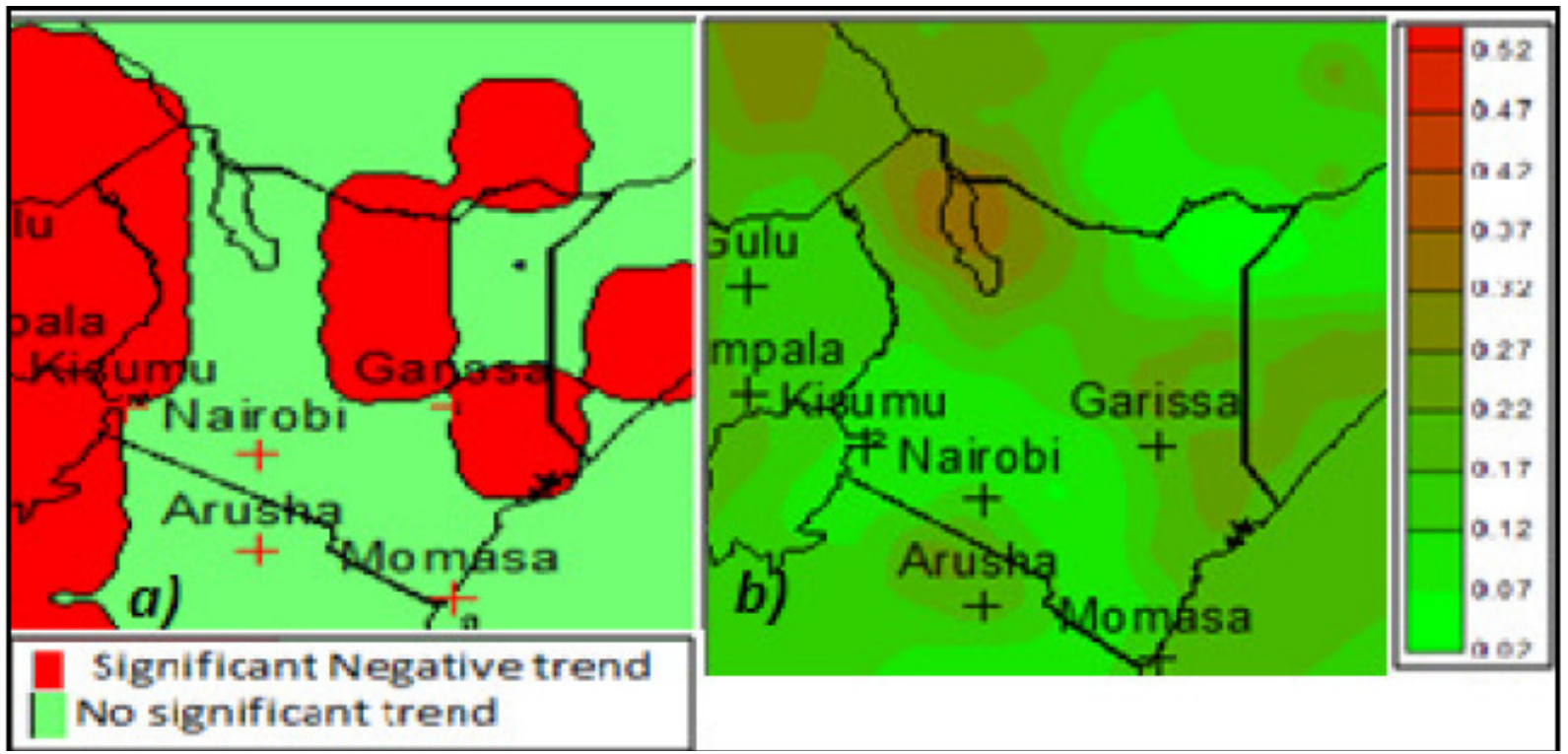

Figure 4: Spatial pattern of a) mean and b) long term AOD over Kenya

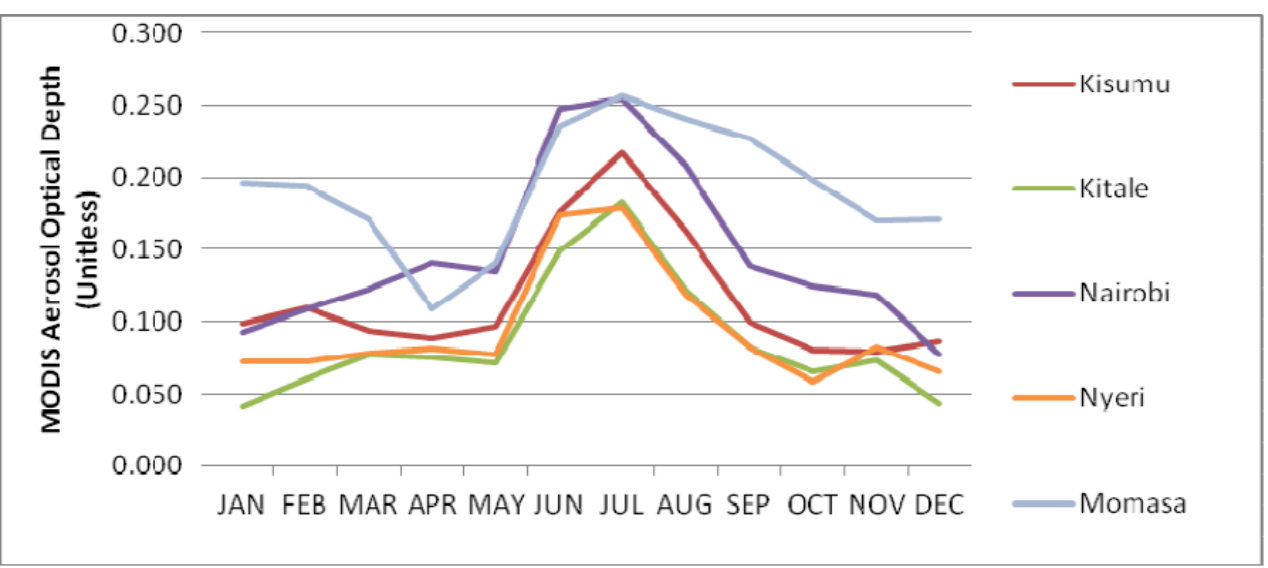

Figure 5: Annual variation of MODIS Aerosol Optical depth over Kenya 


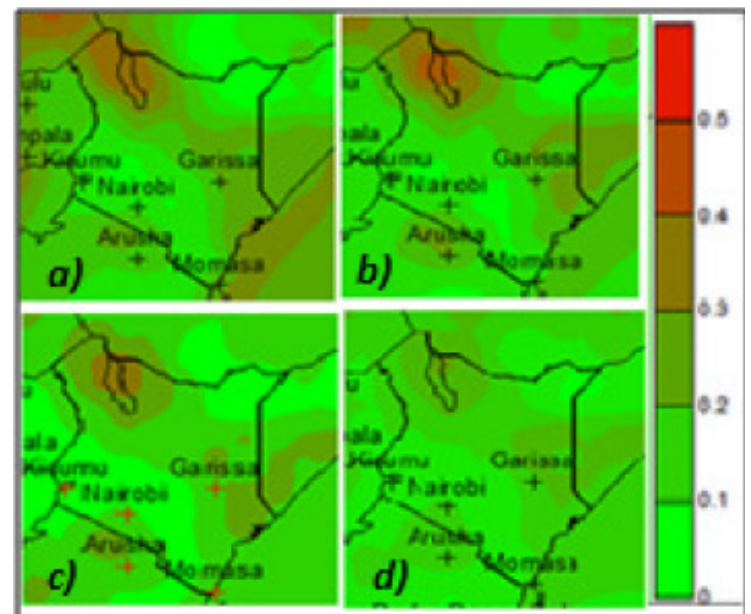

Figure 6: AOD over Kenya during a) DJF b) MAM c) JJA and d) SON season

Influence of meteorological parameters on atmospheric aerosols

Back trajectory analysis was computed at several altitudes $(500 \mathrm{~m}, 1000 \mathrm{~m}$, and $500 \mathrm{~m})$ for January,

April, July and October 2012 as representative periods for DJF, MAM, JJA and SON seasons as shown in (figure 7).

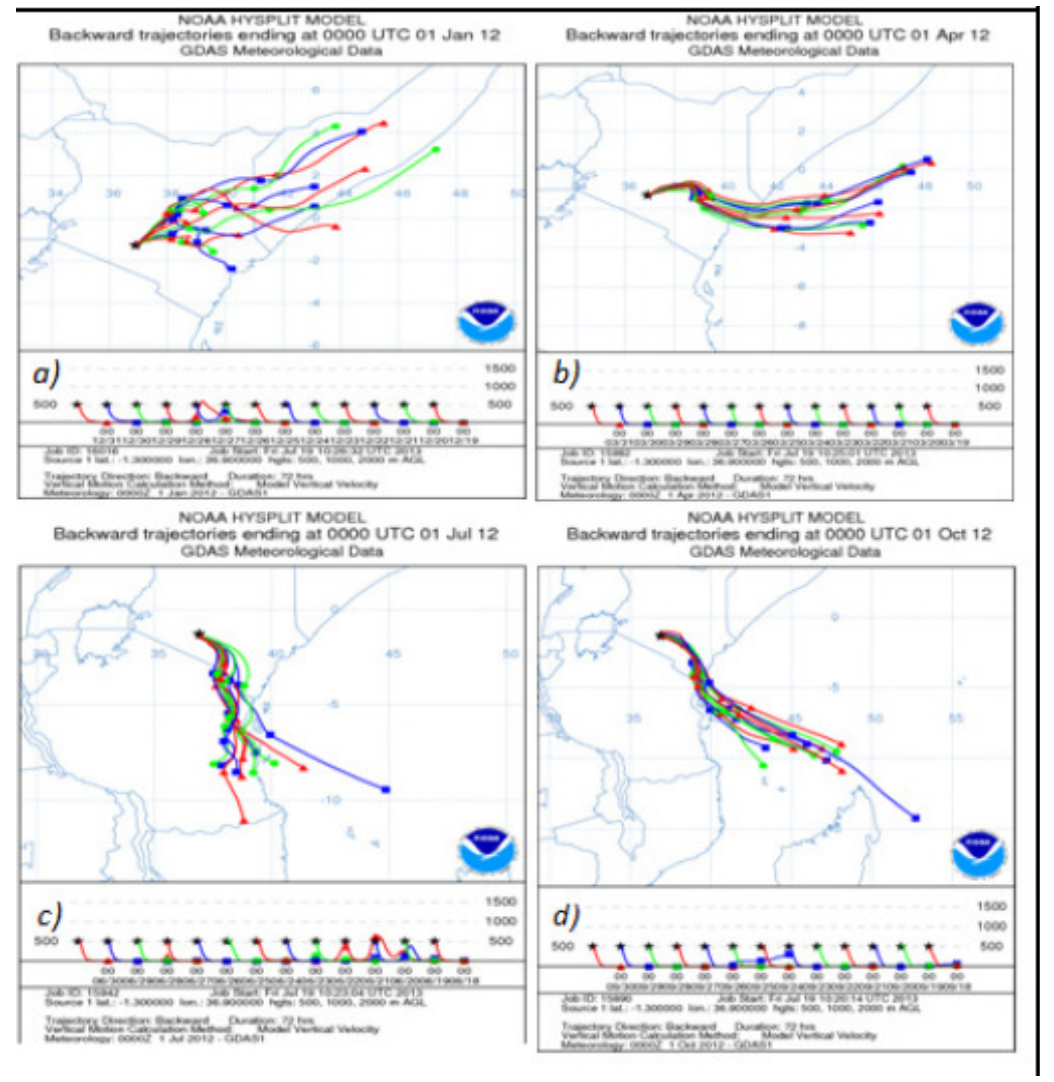

Figure 7: Back trajectories for a) DJF b) MAM c) JJA and d) SON over Kenya

The results indicated that the sources of pollutants during DJF and MAM were mainly from the Arabian highs and Indian Sub continent while sources of pollutants during the JJA and 
SON season were mainly from the southwestern parts of the Indian Ocean. Studies by Gatebe et al. (2001) noted that aerosols measured depended critically on regional patterns of aerosol transport with interregional transfers seemingly a feature of the transport climatology with inter hemispheric transport across the equator in the region is observed.

Further, the study observed that at different levels above the ground, the atmospheric aerosol present in the atmosphere had same origins. It was assumed that these aerosols at from different origins underwent vertical mixing as they got advected inlands over the region. Therefore, these mixed aerosols accounted for enhanced aerosol loading and significant trend over western parts of the study.

\section{Conclusion}

Assessment of space and time variability of MODIS aerosol measurements over Kenya showed a decreasing trend in aerosol loading with a long term mean of between 0.02 and 0.56 . Although validation of MODIS AOD using AERONET data from two stations (Nairobi and Mbita) indicated that MODIS overestimated the aerosol loading, the data confirmed that MODIS data performed well over vegetated regions than near large water bodies. Time series of mean monthly AOD values showed two peaks during the months of July and December while seasonal variations indicated high aerosol loading during DJF and JJA season. Backward trajectory analysis indicated that the sources of pollutants during DJF and MAM were mainly from the Arabian highs and Indian Sub continent while sources of pollutants during the JJA and SON season were mainly from the southwestern parts of the Indian Ocean. In order to obtain more comprehensive satellite AOD retrievals utilization of long time period AERONET is planned for future research projects aimed at achieving a better understanding of spatial and temporal variations in aerosols over Kenya.

\section{Acknowledgement}

This work is part of the first author Master of Science Thesis. The Authors are grateful to the MODIS (http://modis.gsfc.nasa.gov) team at NASA for the provision of satellite data and AERONET team (http://aeronet.gsfc.nasa.gov/) for provision of ground based AOD data. The author also acknowledges the NOAA Air Recourses Laboratory (ARL) for providing the HYSPLIT transport and dispersion model and the READY portal (http://www.arl.noaa.gov/ready.html) and the technical and academic staff at the Department of Meteorology, University of Nairobi for facilitating preparation of this Article.

\section{References}

Alam, K., Trautmann, T. and Blaschke, T. (2011). Aerosol Optical Properties and radiative forcing over mega city Karachi. Atmospheric Research 101, 773-782

Chu, D.A., Kaufman, Y.J., Zibordi, G., Chern, J.D., Mao, J., Li, C. and Holben, B.N. (2003). Global monitoring air pollution over land from the earth observing systemterra moderate resolution imaging spectroradiometer (MODIS). Journal of Geophysical Research, 108: D21.

De Graaf M, Tilstra L.G, Aben I and Stammes P. (2010). Satellite observations of the seasonal cycles of absorbing aerosols in Africa related to the monsoon rainfall, 1995-2008. Atmospheric Environment, 44: 1274-1283.

Draxler, R.R. and Rolph, G.D. (2003). HYSPLIT (HYbrid Single-Particle Lagrangian Integrated Trajectory) Model Access via the NOAA ARL READY Website. NOAA Air Resour. Lab.,Silver Spring, Md. Available at: http://www.arl.noaa.gov/ready/hysplit4.html.

Dubovik, O., Smirnov, A., Holben, B.N., King, M.D., Kaufman, Y.J., Eck, T.F. and Slutsker, I. (2000). Accuracy assessments of aerosol optical properties retrieved from aerosol robotic network (AERONET) sun and sky radiance measurements. Journal of Geophysical Research 105, 97919806.

Gatebe, C. K., Tyson, P. D., Annegarn, H. J., Helas, G., Kinyua, A. M. and Piketh, S. J. (2001). Characterization and transport of aerosols over equatorial eastern Africa, Global Biogeochem. Cycles, 15(3): 663672. 
Monitoring Spatial-Temporal Variability of Aerosol over Kenya.................NGAINA et al.

Gautam, R., Hsu, N. C. and Lau, K-M. (2010) Premonsoon aerosol characterization and radiative effects over the Indo-Gangetic Plains: Implications for regional climate warming, J. Geophys. Res., 115: D17208, doi:10.1029/2010JD013819

Gupta, P., Christopher, P.A., Wang, J., Gehring, R., Lee, Y. and Kumar, N. (2008). Satellite remote sensing of particulate matter and air quality assessment over global cities. Atmospheric Environment, 40: 5880-5892.

Haywood, J.M., Francis, P.N., Glew, M.D. and Taylor, J.P. (2001). Optical properties and direct radiative effect of Saharan dust: a case study of two Saharan dust outbreaks using aircraft data. Journal of Geophysical Research, 106: 18417 -18430.

Helsel, D.H. and Hirsch, R.M. (1999). Statistical Methods in Water Resources, Elsevier Science Publishers, Amsterdam,

Holben, B.N., Eck, T.F., Slutsker, I., Tanré, D., Buis, J.P., Setzer, A., Vermote, E., Reagan, J.A., Kaufman, Y.J., Nakajima, T., Lavenu, F., Jankowiak, I. and Smirnov, A. (1998). AERONET- A federated instrument network and data archive for aerosol characterization. Remote Sensing of Environment, 66: 1-16.

Intergovernmental Panel on Climate Change (IPCC). (2007). Climate Change: The Physical Science Basis. Cambridge University Press, New York, pp. 131e216.

Ichoku, C., Kaufman, Y.J. Remer, L.A. and Levy R. (2004). Global aerosol remote sensing from MODIS, Advances in Space Research, 34(4): 820-827.

Kahn, R. A., Garay, M. J. Nelson, D. L. Yau, K. K. Bull, M. A. Gaitley, B. J. Martonchik, J. V. and Levy, R. C. (2007). Satellite-derived aerosol optical depth over dark water from MISR and MODIS: Comparisons with AERONET and implications for climatological studies, J. Geophys. Res., 112: D18205.

Kaufman, Y.M., Koren, I., Remer, L.A., Rosenfield, D. and Rudich, Y. (2005). The effect of smoke, dust, and pollution aerosol on shallow cloud development over the Atlantic Ocean. Proceedings of the National Academy of Sciences 102, 1120711212
Kosmopoulos, P.G., Kaskaoutis, D.G., Nastos, P.T. and Kambezidis, H.D. (2008). Seasonal variation of columnar aerosol optical properties over Athens, Greece, based on MODIS data. Remote Sensing of Environment 112: 2354-2366.

Liu, Y., Franklin, M., Kahn, R. and Koutrakis, P. (2007). Using aerosol optical thickness to predict ground-level PM concentrations in the St. Louis area: a comparison between MISR and MODIS. Remote Sensing of Environment 107, 33-44.

Lohmann, U. and Feichter, J. (2005). Global indirect aerosol effects: a review. Atmospheric Chemistry and Physics 5: 715737.

Matheson, M.A., Coakley, J.A. and Tahnk, W.R. (2005). Aerosol and cloud property relationships for summertime stratiform clouds in the northern Atlantic from advanced very high resolution radiometer observations. Journal of Geophysical Research, 110: D24204.

Mbithi, D.M. (2010). Transport and dispersion patterns of aerosols over the east African region. Master Of Science Thesis, Department of Meteorology, University of Nairobi

Mkoma, S.L. and Mjemah, I.C. (2011). Influence of Meteorology on Ambient Air Quality in Morogoro, Tanzania. International Journal of Environmental Sciences 1(6): 11071115.

Ngaina, J.N. and Mutai, B.K. (2013). Observational evidence of climate change on extreme events over East Africa. Journal of Global Meteorology, 2(1): 6-12.

Otto, S., de Reus, M., Trautmann, T., Thomas, A., Wendisch, M. and Borrmann, S. (2007). Atmospheric radiative effects of an in situ measured Saharan dust plume and the role of large particles. Atmospheric Chemistry and Physics 7: 4887-4903.

Papadimas, C.D., Hatzianastassiou, N., Mihaloppoulos, N., Kanakidou, M., Katsoulis, B.D. and Vardavas, I. (2008). Assessment of the MODIS collections C005 and C004 aerosol optical depth products over the Mediterranean basin. Atmospheric Chemistry and Physics, 9: 2987-2999. 
Prasad, A.K. and Singh, R.P. (2007). Comparison of MISR-MODIS aerosol optical depth over the Indo-Gangetic basin during the winter and summer seasons (2000 -2005). Remote Sensing of Environment, 107: 109-119.

Rajeev, K., Ramanathan, V. and Meywerk, J. (2000). Regional aerosol distribution and its long-range transport over the Indian Ocean; J. Geophys. Res. 105: 2029-2043.

Smart, J.C.R., Hicks, K., Morrissey, T., Heinemeyer, A., Sutton, M.A. and Ashmore, M. (2011). Applying the ecosystem service concept to air quality management in the UK: a case study for ammonia. Environmetrics, 22: 649-661.
Torres, O., Bhartia, P.K., Herman, J.R., Sinyuk, A., Ginoux, P. and Holben, B.N. (2002). A long-term record of aerosol optical depth from TOMS observations and comparison to AERONET measurements. Journal of Atmospheric Science, 59: 398413.

Wang, J. and Christopher, S.A. (2003). Intercomparison between satellite-derived aerosol optical thickness and PM2.5 mass: implications for air quality studies. Geophysical Research Letters 30. doi:10.1029/2003GL018174. 